\title{
EVALUASI PELAKSANAAN PEMBELAJARAN SENI BUDAYA SMA DI KABUPATEN LOMBOK TIMUR, NTB
}

\author{
1) Jien Tirta Rabarja, ${ }^{2)}$ Trie Hartiti Retnowati \\ ${ }^{1)}$ IKIP Mataram, ${ }^{2}$ Universitas Negeri Yogyakarta \\ 1)jienraharja@yahoo.com, ${ }^{2}$ tri_hartiti@yahoo.com
}

\begin{abstract}
Abstrak
Tujuan penelitian ini adalah mendeskripsikan pelaksanaan pembelajaran Seni Budaya di SMA Kabu-paten Lombok Timur. Pelaksanaan pembelajaran Seni Budaya dideskripsikan sesuai Permendiknas No.41 Tahun 2007, yang meliputi empat komponen, yaitu perencanaan, pelaksanaan, penilaian, dan pengawasan proses pembelajaran. Penelitian ini merupakan penelitian evaluasi dengan pendekatan kuantitatif deskriptif menggunakan Model Evaluasi Kesenjangan terdiri dari tiga tahap yaitu tahap telaah standar, tahap deskripsi penampakan di lapangan, dan tahap komparasi penampakan dengan standar yang ditetapkan. Sampel penelitian terdiri dari 5 sekolah negeri dan 3 sekolah swasta di Kabupaten Lombok Timur, dengan jumlah responden 256 orang, terdiri atas 8 guru Seni Budaya, 8 Kepala Sekolah, dan 240 siswa. Pengumpulan data menggunakan teknik observasi, angket, dan analisis dokumen. Instrumen pengumpulan data terdiri dari lembar observasi, angket, dan lembar dokumentasi. Validasi instrumen dilakukan dengan metode Expert Judgement, dan uji reliabilitas instrumen angket menggunakan estimasi Alpha Cronbach dengan koefisien sebesar 0,725. Data yang terkumpul dianalisis dengan teknik deskriptif kuantitatif. Kesimpulan hasil penelitian ini sebagai berikut. (1) Perencanaan proses pembelajaran kurang baik; (2) Pelaksanaan proses pembelajaran kurang baik; (3) Penilaian proses pembelajaran cukup baik; (4) Pengawasan proses pembelajaran kurang baik; (5) Secara keseluruhan, ada kesenjangan antara pelaksanaan proses pembelajaran Seni Budaya SMA di Kabupaten Lombok Timur dengan standar minimal Permendiknas No.41 Tahun 2007.
\end{abstract}

Kata kunci: seni budaya

\section{AN EVALUATION OF CULTURAL ARTS LEARNING PROCESS AT SENIOR HIGH SCHOOLS IN LOMBOK TIMUR REGENCY, NTB}

\begin{abstract}
This study aims at describing the Cultural Arts learning at senior high schools in East Lombok district. The Cultural Arts learning was described based on the Decree of Minister of National Education No. 41 of 2007, which involves four components, i.e. planning, implementation, assessment, and supervision of the learning process. The study was an evaluation research using a quantitative descriptive approach. The evaluation model used in this research was discrepancy evaluation model with three phases: standard analysis, description of the actual performances in the field, and comparison between the actual performances and the established standards. The samples were 5 public and 3 private schools in East Lombok Regency with 256 respondents, consisting of 8 Cultural Art teachers, 8 school principals, and 240 students. The data were collected by using observation technique, questionnaire, and documentation. The data collection instruments were observation sheets, questionnaires, and documentation sheets. Validation of the instrument was conducted by using expert judgement. To test the questionnaire reliability, this study used Alpha Cronbach estimation with a coefficient of 0.725. The collected data were analyzed using quantitative descriptive techniques. The results are as follows. (1) The planning of learning is not yet maximum; (2) The learning process is not yet maximum; (3) The assessment of the learning processes is quite good; (4) The supervision of the learning process also is not yet optimal; (5) In general, there is a discrepancy between the implementation of the learning process and the minimum standards which have been set in the Decree of the Minister of National Education No.41 of 2007.
\end{abstract}

Keyword: cultural arts 


\section{Pendahuluan}

Krisis moral remaja usia sekolah tengah menjadi isu serius di Indonesia. Hal ini terlihat dari maraknya kasus-kasus kriminal yang melibatkan remaja usia sekolah. Data Badan Pusat Statistik (BPS) menunjukkan, selama tahun 2009 sekitar 49.372 orang pelaku kriminal di Indonesia adalah remaja usia sekolah menengah atas atau sederajat. Jumlah tersebut sedikit menurun pada tahun 2010 menjadi 47.270 orang pelaku (BPS, 2011, p.58). Jumlah tersebut tentunya sangat banyak dan memrihatinkan.

Tindak kriminal remaja usia sekolah seharusnya tidak terjadi. Remaja usia sekolah sebaiknya diarahkan untuk melakukan kegiatan-kegiatan positif yang lebih bermanfaat dalam melatih kecerdasan emosi mereka. Salah satunya melalui kegiatan seni. Kegiatan seni di Indonesia terwujud dalam pendidikan seni, yang bertujuan membentuk peserta didik menjadi pribadi yang harmonis dengan memerhatikan kebutuhan perkembangannya dalam mencapai multikecerdasan; kecerdasan musikal, spasial, moral, spiritual, emosional dan lainnya (Kementrian Pendidikan Nasional, 2006, p.225). Artinya, tindak kriminal yang terjadi selama ini setidaknya dapat berkurang apabila remaja usia sekolah diarahkan untuk melakukan kegiatan seni, baik di sekolah maupun luar sekolah.

Kenyataan yang terjadi selama ini, kegiatan seni yang dilakukan anak atau remaja usia sekolah masih sangat kurang. Anak lebih tertarik melakukan kegiatan lain yang dapat dikatakan kurang bermanfaat, seperti menonton TV. Hal ini tampak pada hasil Susenas BPS tahun 2009 yang menemukan bahwa hanya 9,95\% anak usia 5-17 tahun (baik laki-laki maupun perempuan) yang menonton/melakukan kegiatan seni. Berbeda jauh dibanding remaja yang lebih suka menonton TV sebesar 93\%; membaca sebesar $78,91 \%$, dan mendengarkan radio sebesar 16, 58\% (KPP dan PA, 2011, p.73).

Kegiatan seni anak usia sekolah seharusnya dioptimalkan, terutama di sekolah itu sendiri. Pemerintah telah mengatur bahwa kegiatan seni diberikan melalui pendidikan seni di sekolah. Pendidikan seni tersebut terwujud dalam pembelajaran Seni Budaya dan wajib dilaksanakan di setiap jenjang pendidikan. Hal ini sebagaimana diatur dalam Undang-Undang Sisdiknas No. 20 Tahun 2003 Pasal 37 Ayat $1 \mathrm{~g}$ bahwa setiap kurikulum satuan pendidikan dasar dan menengah wajib memuat mata pelajaran Seni Budaya. Selanjutnya, Peraturan Pemerintah (PP) No. 19 Tahun 2005 Pasal 6 Ayat 1 dan Peraturan Menteri Pendidikan Nasional (Permendiknas) No. 22 Tahun 2006, mengatur bahwa muatan Seni Budaya tersebut termasuk dalam cakupan kelompok mata pelajaran estetika.

Peraturan tersebut menunjukkan bahwa pendidikan seni bersifat penting, dan wajib dilaksanakan secara maksimal di setiap jenjang pendidikan. Hal ini agar fungsi pendidikan seni dalam membentuk pribadi peserta didik yang harmonis dan mencapai multikecerdasan dapat berjalan maksimal. Logikanya, optimalisasi fungsi pendidikan seni tersebut dapat dicapai apabila pelaksanaan pembelajaran Seni Budaya dilakukan dan berjalan dengan maksimal.

Faktanya, masih banyak kendala dalam pelaksanaan pembelajaran Seni Budaya di Indonesia. Salah satu kendala yakni terbatasnya ketersediaan guru yang ahli/berlatar belakang pendidikan seni. Data yang dirangkum oleh Pusat Pengembangan dan Pelatihan Pendidik dan Tenaga Kependidikan (P4TK) Seni Budaya Yogyakarta pada tahun 2010 juga menunjukkan terbatasnya ketersediaan guru seni di beberapa daerah. Dari jumlah total 22.672 guru seni yang terdaftar dan memiliki Nomor Urut Pendidik dan Tenaga Kependidikan (NUPTK), masih banyak guru seni yang bukan berlatar belakang seni, baik itu seni kerajinan, seni rupa, musik, tari maupun seni teater.

Demikian halnya di Kabupaten Lombok Timur, Provinsi Nusa Tenggara Barat. Kurangnya guru dengan kualifikasi dan kompetensi khusus di bidang seni, menjadi kendala dalam pelaksanaan pembelajaran Seni Budaya di Kabupaten Lombok Timur. Kendala tersebut terutama di jenjang seko- 
lah menengah seperti SMA. Guru seni yang tersedia, tidak dapat memenuhi kebutuhan guru seni di Kabupaten Lombok Timur.

Berdasarkan studi awal yang dilakukan, jumlah guru seni yang tersedia dengan jumlah SMA yang ada di Kabupaten Lombok Timur tidak seimbang. Data Dinas Pendidikan dan Kebudayaan Kabupaten Lombok Timur (per 1 Agustus 2012) menunjukkan, dari 22 SMA negeri di Kabupaten Lombok Timur, diketahui sekolah yang guru seninya terdaftar hanya 5 (lima) sekolah. Jumlah tersebut terdiri atas 4 (empat) guru dengan latar belakang seni, dan 1 (satu) guru dengan latar belakang nonseni. Demikian halnya dengan SMA swasta. Dari jumlah total 27 sekolah tidak satu pun data guru Seni Budaya yang terekam di dinas pendidikan setempat. Data tersebut sekaligus menunjukkan bahwa di Kabupaten Lombok Timur, jumlah guru seni dengan kualifikasi akademik yang sesuai masih sangat kurang.

Studi awal juga menunjukkan bahwa untuk memenuhi kebutuhan guru seni, banyak SMA di Kabupaten Lombok Timur yang memberdayakan guru mata pelajaran lain untuk mengampu pelajaran seni. Secara kualifikasi, mereka tidak berasal dari bidang seni, namun mereka memiliki pengalaman otodidak di bidang seni, seperti guru seni bidang musik di SMAN 2 Selong. Guru tersebut berijazah S1 Antropologi, akan tetapi memiliki pengalaman menjadi pemain grup musik (band) dan memiliki kemampuan bernyanyi. Contoh lainnya, di SMAN $1 \mathrm{Ke}-$ ruak, yang guru seninya tidak memiliki kualifikasi akademik bidang seni, akan tetapi guru tersebut memiliki pengalaman sebagai seorang pemusik (gitaris). Hal demikian terjadi di hampir 90\% SMA negeri maupun swasta di Kabupaten Lombok Timur.

Selain itu, kekosongan pengampu mata pelajaran seni di Kabupaten Lombok Timur banyak diisi oleh guru yang berasal dari luar pulau Lombok, seperti Jawa dan Bali. Secara kualifikasi, guru-guru dari luar Lombok rata-rata berijazah D3 di bidang seni, akan tetapi mereka tidak selamanya di Lombok. Setelah menjadi PNS dan seiring bertambahnya usia, mereka pun kembali ke daerah asal masing-masing. Adapun guru yang memilih berdomisili tetap di Lombok adalah mereka yang menikah dengan orang asli Lombok. Dengan kondisi yang demikian, berarti kekosongan pengampu mata pelajaran seni di SMA Kabupaten Lombok Timur tetap ada.

Pemenuhan kebutuhan guru seni budaya, sebenarnya dapat dilakukan dengan mengarahkan putra dan putri daerah lulusan SMA untuk melanjutkan kuliah di bidang pendidikan seni, seperti yang dilakukan Pemerintah Provinsi Kalimantan Barat (Pontianak). Antisipasi yang dilakukan pemerintah Pontianak, khususnya Kabupaten Landak adalah menjalin kerja sama dengan LPTK yang menyelenggarakan pendidikan seni di luar daerah, dan memberikan beasiswa kepada putra putri daerah untuk mengikuti pendidikan di perguruan tinggi tersebut, kemudian setelah lulus mereka harus kembali dan mengajar di daerah asal (Ghazali, 2010, pp.57-58).

Langkah di atas seharusnya dapat dijadikan referensi oleh Pemerintah Kabupaten Lombok Timur dalam menanggulangi keterbatasan guru seni. Pemerintah harus menyadari bahwa terbatasnya ketersediaan guru seni akan berdampak pada kurang maksimalnya pelaksanaan pembelajaran Seni Budaya SMA di Kabupaten Lombok Timur. Pelajaran tersebut memiliki karakteristik yang khas dan unik, maka dibutuhkan guru yang memiliki kualifikasi dan keahlian khusus di bidang seni agar pelaksanaan proses pembelajaran dapat dilaksanakan sesuai standar yang ditetapkan pada Permendiknas No. 41 Tahun 2007. Selain itu, Permendiknas No. 16 Tahun 2007 juga telah mengatur bahwa guru harus memiliki kualifikasi minimal S1/D4 yang diperoleh dari perguruan tinggi terakreditasi, dan mengampu pelajaran yang sesuai dengan jurusannya.

Temuan lain dari studi awal pada pelaksanaan pembelajaran Seni Budaya SMA di Kabupaten Lombok Timur adalah alokasi waktu pelajaran Seni Budaya kerap digunakan untuk mata pelajaran lain. Hal ini terjadi terutama menjelang dilaksanakannya Ujian 
Akhir Nasional (UAN), tidak sedikit sekolah yang menggunakan alokasi waktu pelajaran seni untuk mengajarkan materi pelajaran lain yang akan di UAN-kan, sehingga pelajaran seni tidak diajarkan. Keadaan tersebut meninggalkan kesan bahwa pelajaran seni dikesampingkan atau dinomor duakan.

Permasalahan-permasalahan dalam pelaksanaan pembelajaran Seni Budaya SMA di Kabupaten Lombok Timur, sebenarnya telah diketahui banyak pihak. Ironisnya, belum pernah ada pihak yang mengevaluasi secara empiris seperti apa pelaksanaan pembelajaran Seni Budaya SMA di Kabupaten Lombok Timur, terlebih dengan kondisi terbatasnya ketersediaan guru seni. Oleh karena itu, maka penting untuk dilakukan penelitian ini, guna mengevaluasi secara empiris seperti apa sebenarnya pelaksanaan pembelajaran Seni Budaya SMA di Kabupaten Lombok Timur.

Seperti diuraikan sebelumnya, fokus masalah dalam penelitian ini adalah seperti apa pelaksanaan pembelajaran Seni Budaya SMA di Kabupaten Lombok Timur. Dengan demikian, tujuan penelitian ini adalah mendeskripsikan pelaksanaan pembelajaran tersebut. Diharapkan, hasil penelitian ini dapat bermanfaat untuk pengambil kebijakan di Kabupaten Lombok Timur, dan dapat menambah khazanah pengetahuan di bidang pendidikan seni bagi pihak yang membutuhkan.

\section{Metode Penelitian}

Jenis Penelitian

Penelitian ini merupakan penelitian evaluasi pendekatan kuantitatif deskriptif. Model evaluasi yang digunakan adalah Discrepancy Evaluation Model yang dikembangkan oleh Malcolm Provus. Ada 3 tahap evaluasi yang dilakukan dalam penelitian ini, yaitu tahap Standart, Program, dan Comparison. Pada tahap Standart, dilakukan telaah terhadap standar baku yang ditetapkan pemerintah. Pada tahap Program, dilakukan pendeksripsian keterlaksanaan program di lapangan. Pada tahap Comparison, dilakukan pendeskripsian komparasi atau kesenjangan antara keterlaksanaan program dengan standar yang ditetapkan.

\section{Populasi dan Sampel}

Populasi dalam penelitian ini adalah Sekolah Menengah Atas (SMA) Negeri dan Swasta di Kabupaten Lombok Timur. SMA Negeri berjumlah 22 sekolah, dan SMA Swasta berjumlah 27 sekolah. Sampel penelitian terdiri dari 5 (lima) sekolah negeri (SMA N 1 Selong, SMA N 2 Selong, SMA N 1 Sakra, SMA N 1 Aikmel, SMA N 1 Masbagik) dan 3 (tiga) sekolah swasta (SMA Yadinu Masbagik, SMA Birul Walidain Rensing, SMA NW Pancor). Sampel diambil menggunakan teknik purposive sampling.

Selanjutnya, responden pada penelitian ini terdiri dari kepala sekolah, guru, dan Siswa. Jumlah total keseluruhan responden sebanyak 256 responden terdiri dari $8 \mathrm{Ke}-$ pala sekolah, 8 guru Seni Budaya, dan 240 siswa.

Variabel Penelitian

Pelaksanaan pembelajaran Seni Budaya dalam penelitian ini merujuk pada Permendiknas No. 41 Tahun 2007 tentang Standar Proses Pembelajaran. Dengan demikian, variabel dalam penelitian ini sebagai berikut: (1) Perencanaan pembelajaran Seni Budaya SMA, terkait bagaimana guru merencanakan pembelajaran ditinjau dari komponen RPP; (2) Pelaksanaan proses pembelajaran Seni Budaya SMA, terkait bagaimana guru melaksanakan proses pembelajaran, ditinjau dari komponen persyaratan pembelajaran dan pelaksanaan kegiatan pembelajaran yang meliputi kegiatan awal atau pendahuluan, kegiatan inti, dan kegiatan penutup; (3) Penilaian pembelajaran Seni Budaya SMA, terkait bagaimana guru melakukan penilaian, ditinjau dari teknik penilaian yang digunakan guru, instrumen penilaian, dan analisis hasil pembelajaran; (4) Pengawasan pembelajaran Seni Budaya SMA, terkait bagaimana pihak sekolah (kepala sekolah) melakukan pengawasan terhadap pembelajaran 
Seni Budaya mulai dari tahap perencanaan, pelaksanaan, dan penilaian pembelajaran Seni Budaya SMA.

\section{Setting Penelitian}

Penelitian ini dilakukan di 6 (enam) kecamatan di Kabupaten Lombok Timur, Provinsi Nusa Tenggara Barat. Rinciannya adalah 2 SMA di Kecamatan Selong, 2 SMA di Kecamatan Masbagik, 1 SMA di Kecamatan Aikmel, 1 SMA di Kecamatan Sakra, 1 SMA di Kecamatan Pancor, dan 1 SMA di Kecamatan Sakra Barat. Pengambilan data dilakukan mulai bulan Maret sampai dengan April 2013.

Teknik Pengumpulan Data dan Instrumen Penelitian

Teknik pengumpulan data yang digunakan dalam penelitian ini adalah angket (kuesioner), observasi, dan dokumentasi. Angket digunakan untuk memperoleh informasi tentang pelaksanaan dan pengawasan proses pembelajaran Seni Budaya SMA di Kabupaten Lombok Timur. Angket diberikan kepada para responden yakni siswa dan kepala sekolah. Observasi dilakukan terhadap pelaksanaan pembelajaran di kelas. Aspek yang diobservasi yakni pelaksanaan kegiatan pembelajaran di kelas oleh guru, meliputi kegiatan awal, kegiatan inti, dan kegiatan penutup. Selain itu, ada butir khusus yang berisi saran pengawas terhadap guru yang bersangkutan. Observasi dilakukan oleh observer yakni peneliti sendiri bekerja sama dengan 8 pengawas pembina masing-masing sekolah. Hal ini dilakukan agar kredibilitas observer dapat dipercaya, dengan pertimbangan pengawas pembina lebih mengetahui kondisi tiap sekolah, sehingga memudahkan observasi.

Selanjutnya, digunakan juga teknik dokumentasi yang dilakukan untuk melakukan penilaian terhadap dokumen-dokumen terkait. Dokumen yang dinilai terkait perencanaan pembelajaran (RPP) dan dokumen penilaian pembelajaran Seni Budaya. Penilaian dokumen dilakukan dengan cara memberi skor sesuai kuantifikasi ketersedia- an dokumen penilaian yang dimiliki guru. Pengecekan dokumen dilakukan pula oleh observer yang telah disebutkan yakni pengawas pembina di tiap sekolah.

Instrumen yang digunakan pada penelitian ini adalah angket, lembar/pedoman observasi, dan Lembar Penilaian Dokumen. Angket diberikan kepada siswa dan kepala sekolah. Angket yang diberikan kepada siswa adalah angket untuk mengukur variabel pelaksanaan pembelajaran, terdiri dari 22 butir dengan rincian 1 butir pertanyaan uraian (terbuka, 21 butir pertanyaan tertutup dimana 5 butir mengukur komponen persyaratan pelaksanaan pembelajaran, dan 16 butir mengukur komponen pelaksanaan kegiatan pembelajaran. Angket yang diberikan kepada kepala sekolah adalah angket untuk mengukur variabel pengawasan proses pembelajaran. Angket untuk kepala sekolah berisi 12 butir, yang di dalamnya ada 7 butir yang di skor (tertutup) dan 5 butir lainnya berbentuk isian dan uraian (terbuka).

Selain angket, instrumen yang digunakan dalam penelitian ini adalah lembar observasi dan lembar penilaian dokumen. Lembar/pedoman observasi digunakan untuk mengukur bagaimana guru melaksanakan pembelajaran di kelas yang meliputi kegiatan awal, kegiatan inti, dan kegiatan penutup. Lembar/pedoman observasi diisi oleh observer seperti yang telah dikemukakan sebelumnya. Instrumen lembar penilaian dokumen digunakan untuk mengukur variabel perencanan pembelajaran dan penilaian pembelajaran. Lembar penilaian dokumen disertai juga dengan butir khusus saran perbaikan, catatan prestasi, dan catatan fasilitas penunjang pembelajaran Seni Budaya sebagai informasi tambahan.

\section{Validitas dan Reliabilitas}

Uji validitas instrumen dilakukan dengan teknik validitas isi. Uji validitas isi dilakukan dengan metode validasi ahli atau expert judgement. Validasi isi dilakukan oleh 2 (dua) orang ahli yakni Dr. Heri Retnawati, M.Pd. dan Dr. Kun Setyaning Astuti, M.Pd. Validitas isi dengan metode validasi diguna- 
kan karena konstruk instrumen dalam penelitian ini telah baku, yakni mengacu pada standar yang telah ditetapkan oleh pemerintah. Uji reliabilitas instrumen menggunakan estimasi Cronbach Alpha dengan melihat koefisien reliabilitasnya. Adapun instrumen yang dapat diuji koefisien reliabilitasnya dalam penelitian ini adalah instrumen angket dengan responden siswa. Koefisien reliabilitas instrumen angket pada penelitian ini sebesar 0,725 .

\section{Teknik Analisis Data}

Data yang diperoleh dalam penelitian ini dianalisis secara deskriptif kuantitatif. Analisis secara deskriptif kuantitatif dapat dilakukan dengan dengan menentukan statistik data tersebut, seperti menentukan ukuran data atau tendensi sentral (mean, median, modus), ukuran variabilitas (simpangan baku dan range), dan frekuensi (Kosecoff dan Fink, 1982, p.178). Pada penelitian ini, analisis data-data yang telah terkumpul dilakukan dengan mengacu pada kriteria yang telah ditentukan sebelumnya berdasarkan rata-rata ideal dan simpangan baku ideal yang dicapai oleh instrumen. Menurut Azwar (2012, p.163), kriteria rerata ideal yang dapat digunakan sebagai berikut.

Tabel 1. Kriteria Rerata Ideal

\begin{tabular}{cc}
\hline Interval & Kriteria \\
\hline $\mathrm{X}>\mathrm{M}+1,5 \mathrm{SD}$ & Baik sekali \\
$\mathrm{M}+0,5 \mathrm{SD}<\mathrm{X}<\mathrm{M}+1,5 \mathrm{SD}$ & Baik \\
$\mathrm{M}-0,5 \mathrm{SD}<\mathrm{X}<\mathrm{M}+0,5 \mathrm{SD}$ & Cukup baik \\
$\mathrm{M}-1,5 \mathrm{SD}<\mathrm{X}<\mathrm{M}-0,5 \mathrm{SD}$ & Kurang baik \\
$\mathrm{X}<\mathrm{M}-1,5 \mathrm{SD}$ & Tidak baik \\
\hline
\end{tabular}

Keterangan:

M: rata-rata ideal komponen dalam penelitian, dengan rumus $=1 / 2$ (skor ideal tertinggi dalam komponen + skor ideal terendah)

SD: standar deviasi ideal dalam setiap komponen penelitian dengan rumus $=1 / 6$ (skor ideal tertinggi dalam komponen skor ideal terendah)

\section{Kriteria Evaluasi}

Kriteria evaluasi yang digunakan berbeda-beda di tiap variabel. Pada variabel perencanaan pembelajaran, komponen yang dinilai adalah RPP terdiri dari 17 butir indikator dengan rentang skor 1 s.d. 4. Kriteria evaluasinya sebagai berikut.

Tabel 2. Kriteria Evaluasi Perencanaan Pembelajaran

\begin{tabular}{cc}
\hline Interval & Kriteria \\
\hline $\mathrm{X} \geq 55,25$ & Baik sekali \\
$46,75 \leq \mathrm{X}<55,25$ & Baik \\
$38,25 \leq \mathrm{X}<46,75$ & Cukup baik \\
$29,75 \leq \mathrm{X}<38,25$ & Kurang baik \\
$\mathrm{X}<29,75$ & Tidak baik \\
\hline
\end{tabular}

Pada variabel pelaksanaan pembelajaran, kriteria evaluasi dibagi sesuai teknik pengumpulan data. Pada teknik observasi, ada 5 (lima) komponen yang diukur dengan rentang skor 1 s.d. 4. Kriteria evaluasi secara keseluruhan sebagai berikut.

Tabel 3. Kriteria Evaluasi Keseluruhan Berdasarkan Teknik Observasi

\begin{tabular}{cc}
\hline Interval & Kriteria \\
\hline $\mathrm{X} \geq 16,25$ & Baik sekali \\
$13,75 \leq \mathrm{X}<16,25$ & Baik \\
$11,25 \leq \mathrm{X}<13,75$ & Cukup baik \\
$8,75 \leq \mathrm{X}<11,25$ & Kurang baik \\
$\mathrm{X}<8,75$ & Tidak baik \\
\hline
\end{tabular}

Secara rinci, dalam tiap komponen penskoran dilakukan berdasarkan kuantifikasi kemunculan indikator tiap kegiatan pembelajaran yang dilakukan guru. Rentang skor yang diberikan adalah 1 s.d. 4. Kriteria evaluasi tiap komponen sebagai berikut. 
Tabel 4. Kriteria Evaluasi Tiap Komponen Berdasarkan Teknik Observasi

\begin{tabular}{ccc}
\hline Aspek yang diamati & Interval & Kriteria \\
\hline \multirow{3}{*}{ Kegiatan Awal } & $\mathrm{X} \geq 3,25$ & Baik sekali \\
& $2,75 \leq \mathrm{X}<3,25$ & Baik \\
& $2,25 \leq \mathrm{X}<2,75$ & Cukup baik \\
& $1,75 \leq \mathrm{X}<2,25$ & Kurang baik \\
& $\mathrm{X}<1,75$ & Tidak baik \\
\hline Kegiatan Eksplorasi & $\mathrm{X} \geq 3,25$ & Baik sekali \\
& $2,75 \leq \mathrm{X}<3,25$ & Baik \\
& $2,25 \leq \mathrm{X}<2,75$ & Cukup baik \\
& $1,75 \leq \mathrm{X}<2,25$ & Kurang baik \\
& $\mathrm{X}<1,75$ & Tidak baik \\
\hline Kegiatan Elaborasi & $\mathrm{X} \geq 3,25$ & Baik sekali \\
& $2,75 \leq \mathrm{X}<3,25$ & Baik \\
& $2,25 \leq \mathrm{X}<2,75$ & Cukup baik \\
& $1,75 \leq \mathrm{X}<2,25$ & Kurang baik \\
& $\mathrm{X}<1,75$ & Tidak baik \\
\hline Kegiatan Konfirmasi & $\mathrm{X} \geq 3,25$ & Baik sekali \\
& $2,75 \leq \mathrm{X}<3,25$ & Baik \\
& $2,25 \leq \mathrm{X}<2,75$ & Cukup baik \\
& $1,75 \leq \mathrm{X}<2,25$ & Kurang baik \\
& $\mathrm{X}<1,75$ & Tidak baik \\
\hline & $\mathrm{X} \geq 3,25$ & Baik sekali \\
& $2,75 \leq \mathrm{X}<3,25$ & Baik \\
& $2,25 \leq \mathrm{X}<2,75$ & Cukup baik \\
& $1,75 \leq \mathrm{X}<2,25$ & Kurang baik \\
& $\mathrm{X}<1,75$ & Tidak baik \\
\hline
\end{tabular}

Selanjutnya, pada instrumen angket komponen yang diukur yakni komponen persyaratan pembelajaran (Komponen A) dan komponen pelaksanaan kegiatan pembelajaran (Komponen B). Pada komponen
A, jumlah butir total sejumlah 5 butir, dengan rentang skor 1 s.d. 4. Pada komponen B, jumlah butir total sejumlah 16 butir, dengan rentang skor 1 s.d. 4. Kriteria evaluasinya sebagai berikut.

Tabel 5. Kriteria Evaluasi Instrumen Angket

\begin{tabular}{ccc}
\hline Komponen & Interval & Kriteria \\
\hline & $\mathrm{X} \geq 16,25$ & Baik sekali \\
13,75 & $\leq \mathrm{X}<16,25$ & Baik \\
Komponen $\mathrm{A}$ & $11,25 \leq \mathrm{X}<13,75$ & Cukup baik \\
& $8.75 \leq \mathrm{X}<1,25$ & Kurang baik \\
& $\mathrm{X}<11.25$ & Tidak baik \\
\hline & $\mathrm{X} \geq 52$ & Baik sekali \\
Komponen $\mathrm{B}$ & $44 \leq \mathrm{X}<52$ & Baik \\
& $36 \leq \mathrm{X}<44$ & Cukup baik \\
& $28 \leq \mathrm{X}<36$ & Kurang baik \\
& $\mathrm{X}<28$ & Tidak baik \\
\hline
\end{tabular}


Variabel berikutnya yakni penilaian pembelajaran, teknik yang digunakan adalah dokumentasi. Indikator yang dinilai pada penilaian dokumen ini ada 3 (tiga) dengan rentang skor 1 s.d. 4. Kriteria evaluasinya sebagai berikut.

Tabel 6. Kriteria Evaluasi Penilaian Pembelajaran

\begin{tabular}{cc}
\hline Interval & Kriteria \\
\hline $\mathrm{X} \geq 9,75$ & Baik sekali \\
$8,25 \leq \mathrm{X}<9,75$ & Baik \\
$6,75 \leq \mathrm{X}<8,25$ & Cukup baik \\
$5,25 \leq \mathrm{X}<6,75$ & Kurang baik \\
$\mathrm{X}<5,25$ & Tidak baik \\
\hline
\end{tabular}

Selanjutnya, pada variabel pengawasan pembelajaran, teknik yang digunakan adalah angket dengan responden kepala sekolah. Jumlah butir keseluruhan sejumlah 12 butir, dengan rincian 7 butir yang diskor (pertanyaan tertutup), sedangkan 5 butir lainnya berbentuk isian dan uraian (tidak diskor). Rentang skor 7 butir adalah 1 s.d. 4. Dapat dihitung bahwa skor ideal maksimum sebesar 28, dan skor ideal minimum sebesar 7. Kri-teria evaluasi pada variabel ini sebagai berikut.

Kriteria-kriteria evaluasi di atas digunakan untuk menganalisis dan menginter- pretasi hasil pengolahan data yang diperoleh. Pencapaian rerata skor di lapangan kemudian dikonversi menjadi persentase pencapaian dengan formula sebagai berikut.

$\frac{\text { Rerata Skor Perolehan }}{\text { Rerata Ideal Maksimal tiap Variabel }} \times 100 \%$

Persentase capaian skor variabel menunjukkan seberapa besar keterlaksanaan aspek pelaksanaan pembelajaran Seni Budaya di Kabupaten Lombok Timur dapat dicapai. Besarnya persentase capaian skor selanjutnya digunakan untuk mendeskripsikan kesesuaian antara standar pelaksanaan pembelajaran yang telah ditetapkan dengan performansi di lapangan.

\section{Hasil Penelitian dan Pembahasan}

Perencanaan Pembelajaran

Komponen yang dievaluasi pada variabel ini adalah RPP. RPP yang dimiliki guru di tiap sekolah berbeda, tergantung bidang Seni Budaya yang diajarkan. Penilaian dokumen RPP juga menunjukkan hasil yang berbeda di tiap sekolah. Berikut adalah hasil evaluasi dokumen RPP Seni Budaya SMA di Kabupaten Lombok Timur, yang merefleksikan perencanaan pembelajaran Seni Budaya.

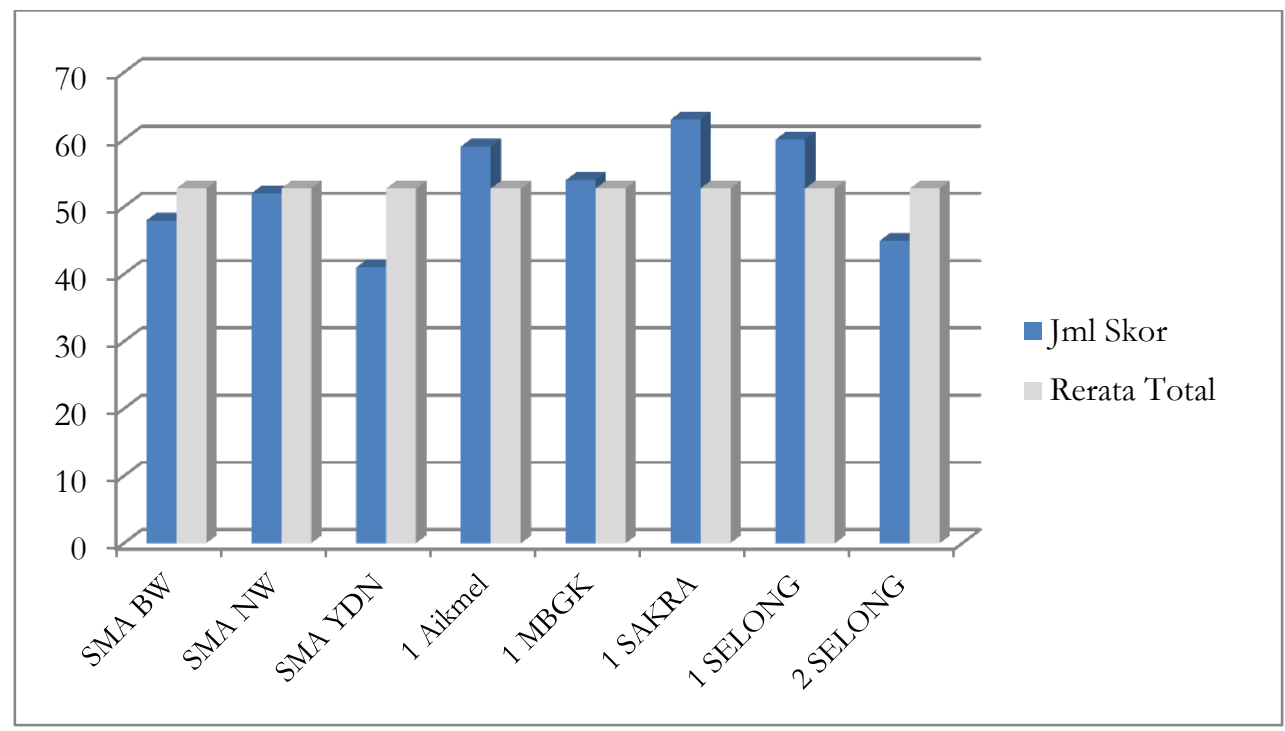

Gambar 1. Pencapaian Skor RPP 
Hasil pengolahan data diperoleh capaian skor rerata total keseluruhan sebesar 52,75 berada pada kategori baik dengan persentase pencapaian $95,4 \%$. Akan tetapi, diagram di atas menunjukkan ada perbedaan capaian rerata skor di tiap sekolah dengan capaian rerata skor keseluruhan. Ada 4 (empat) sekolah yang pencapaian skornya di atas skor rerata total dan ada 4 (empat) sekolah pula yang pencapaian skornya di bawah capaian rerata total. Pencapaian skor tertinggi dicapai SMA N 1 Sakra dengan skor total 63, dan capaian terendah dicapai SMA Yadinu Masbagik dengan skor total 41.

Perolehan skor RPP SMA Birul Walidain Rensing sebesar 48, selisih sekitar 4 poin dengan rerata total sebesar 52,75. RPP yang disusun guru di sekolah ini adalah RPP Seni Kaligrafi (Seni Rupa) untuk kelas XI semester 2. Pencapaian indikator yang masih rendah dalam komponen RPP di sekolah ini adalah guru masih belum baik dalam perencanaan dan penentuan metode, media, dan peralatan pembelajaran yang akan digunakan. Selain itu, guru juga masih belum baik dalam merencanakan pengorganisasian siswa. Hal ini tentunya akan berdampak pada efektivitas pelaksanaan pembelajaran di sekolah ini. Guru Seni Budaya di sekolah ini juga masih belum maksimal dalam merencanakan sumber belajar yang digunakan, dan memperhatikan kesesuaian antara sumber belajar dengan $\mathrm{KD} / \mathrm{SK}$ yang diajarkan.

Serupa dengan SMA Birul Walidain Rensing, perolehan skor RPP di SMA NW Pancor juga berada sedikit di bawah rerata total yakni sebesar 52. RPP yang disusun guru di sekolah ini adalah RPP Seni Kaligrafi (Seni Rupa) untuk kelas X semester 2. Pencapaian indikator yang masih rendah dalam komponen RPP di sekolah ini adalah guru masih belum baik dalam penentuan sumber belajar yang digunakan. Selain itu, guru seni di sekolah ini juga masih belum baik dalam perencanaan pengorganisasian siswa dan merencanakan rancangan kegiatan pembelajaran masih belum maksimal.
Selanjutnya, sekolah dengan perolehan skor RPP di bawah skor rerata total adalah SMA Yadinu Masbagik dengan jumlah rerata skor sebesar 41. RPP yang disusun guru Seni Budaya SMA di sekolah ini adalah RPP Seni Kaligrafi (Seni Rupa) untuk kelas XI. Ada beberapa pencapaian indikator yang masih rendah dalam komponen RPP di sekolah ini. Indikator-indikator tersebut adalah guru masih belum baik dalam menentukan sumber belajar yang digunakan; rancangan kegiatan awal pembelajaran belum maksimal; rancangan jenis dan prosedur penilaian masih belum baik; dan penentuan pengorganisasian siswa masih kurang. Selain itu, guru di sekolah ini juga belum maksimal dalam merancang kegiatan pembelajaran secara keseluruhan, baik itu rancangan kegiatan inti maupun kegiatan akhir pembelajaran.

Seperti halnya dengan yang terjadi di 3 (tiga) sekolah di atas, SMA N 2 Selong juga memiliki kekurangan yang hampir sama sehingga menyebabkan perolehan skor RPP di bawah rerata total yakni sebesar 45. RPP yang disusun oleh guru Seni Budaya di sekolah ini adalah RPP Seni Rupa untuk kelas XI. Pencapaian indikator yang masih rendah hampir sama dengan ketiga sekolah sebelumnya yakni terkait penentuan sumber belajar, penentuan metode, media, dan peralatan pembelajaran, serta masih belum maksimal dalam merancang kegiatan pembelajaran.

Keempat sekolah dengan pencapaian skor di bawah rerata total tersebut terdiri dari 3 (tiga) sekolah swasta dan 1 (satu) sekolah negeri. Sekolah swasta dimaksud adalah SMA Birul Walidain Rensing, SMA NW Pancor, dan SMA Yadinu Masbagik. Sedangkan untuk sekolah negeri, sekolah dimaksud adalah SMA N 2 Selong.

Latar belakang status sekolah (negeri dan swasta) dapat dijadikan faktor dalam menganalisis penyebab capaian skor RPP sekolah-sekolah tersebut berada di bawah rerata total keseluruhan. Artinya, ada faktor lain yang menjadi penyebab rendahnya capaian tersebut apabila mengacu pada latar belakang status sekolah. Faktor pertama

Evaluasi Pelaksanaan Pembelajaran Seni Budaya SMA - 295 Jien Tirta Raharja, Tri Hartiti Retnowati 
adalah sekolah-sekolah swasta tersebut adalah sekolah Islam, dan kebanyakan di Lombok Timur SMA swastanya berlabel Islam di bawah naungan salah satu yayasan pendidikan Islam, Nahdlatul Wathan. Latar belakang sekolah Islam menyebabkan pembelajaran Seni Budaya di sekolah tersebut tidak sesuai karena yang diajarkan adalah Seni Kaligrafi yang sebenarnya tidak ada dalam kurikulum. Selain itu, guru yang mengajar Seni Budaya di sekolah-sekolah tersebut bukanlah guru dengan latar belakang seni, melainkan guru Pendidikan Agama Islam lulusan Ma'had dan memiliki kemampuan dalam seni kaligrafi.

Latar belakang guru nonseni menjadi faktor kedua penyebab rendahnya capaian skor RPP di sekolah-sekolah tersebut. Artinya, dengan latar belakang nonseni guru yang bersangkutan akan kesulitan dalam merancang kegiatan pembelajaran. Hal ini jelas menunjukkan bahwa capaian skor RPP terendah di sekolah-sekolah tersebut terkait mengorganisasikan pembelajaran, baik itu mengorganisasikan sumber belajar, kesesuaian dengan materi yang diajarkan, rancangan kegiatan belajar, dan penentuan jenis serta prosedur penilaian.

Berdasarkan uraian-uraian tersebut, secara keseluruhan perencanaan pembelajaran Seni Budaya SMA di Kabupaten Lombok Timur dapat dikatakan kurang baik. Secara proporsional, masih ada $50 \%$ sekolah dengan perencanaan pembelajaran yang belum baik, terutama pada sekolah swasta. Perencanaan pembelajaran yang belum baik dapat disebabkan oleh 2 (dua) faktor. Faktor pertama adalah status sekolah yakni sekolah Islam, mengakibatkan mata pelajaran seni yang diajarkan tidak sesuai dengan kurikulum yang ada. Faktor kedua adalah latar belakang guru seni di sekolah-sekolah Islam tersebut bukan berasal dari bidang seni sehingga menyebabkan guru kesulitan dalam merancang kegiatan pembelajaran.

\section{Pelaksanaan Pembelajaran}

Data pelaksanaan pembelajaran Seni Budaya dikumpulkan dengan teknik observasi dan teknik angket. Teknik observasi dilakukan terhadap kegiatan pembelajaran di kelas.

Hasil pengolahan data observasi pembelajaran diperoleh capaian rerata skor total keseluruhan komponen sebesar 15.00 berada pada kategori baik, dengan persentase pencapaian sebesar 92,3\%. Demikian halnya dengan pencapaian tiap komponen kegiatan pembelajaran. Pada komponen kegiatan awal pembelajaran, dan kegiatan eksplorasi, capaian rerata skor sebesar 3,125 dengan persentase pencapaian sebesar 96,1\%. Rerata skor pada komponen kegiatan elaborasi dan kegiatan penutup sebesar 3,00 dengan persentase pencapaian sebesar 92,3\%. Selanjutnya, pada komponen kegiatan konfirmasi, capaian rerata skor sebesar 2,75 dengan persentase pencapaian sebesar 84,1\%. Semuanya berada pada kategori baik, merujuk pada kriteria rerata ideal.

Berikutnya, perbandingan capaian skor rerata total di tiap sekolah disajikan pada Gambar 2. Gambar 2 menunjukkan bahwa ada perbedaan pencapaian skor pelaksanaan pembelajaran di tiap sekolah dengan pencapaian rerata total semua sekolah. Secara keseluruhan, ada 4 (empat) sekolah yang pencapaian skornya di atas skor rerata total dan ada 4 (empat) sekolah pula yang pencapaian skornya di bawah capaian rerata total. Sekolah dengan capaian skor di bawah rerata total yakni SMA Birul Walidain Rensing, SMA NW Pancor, SMA Yadinu Masbagik, dan SMA 1 Masbagik. Pencapaian skor tertinggi dicapai SMA N 1 Sakra dengan skor total 19, dan capaian terendah dicapai SMA Yadinu Masbagik dengan skor total 11 . 


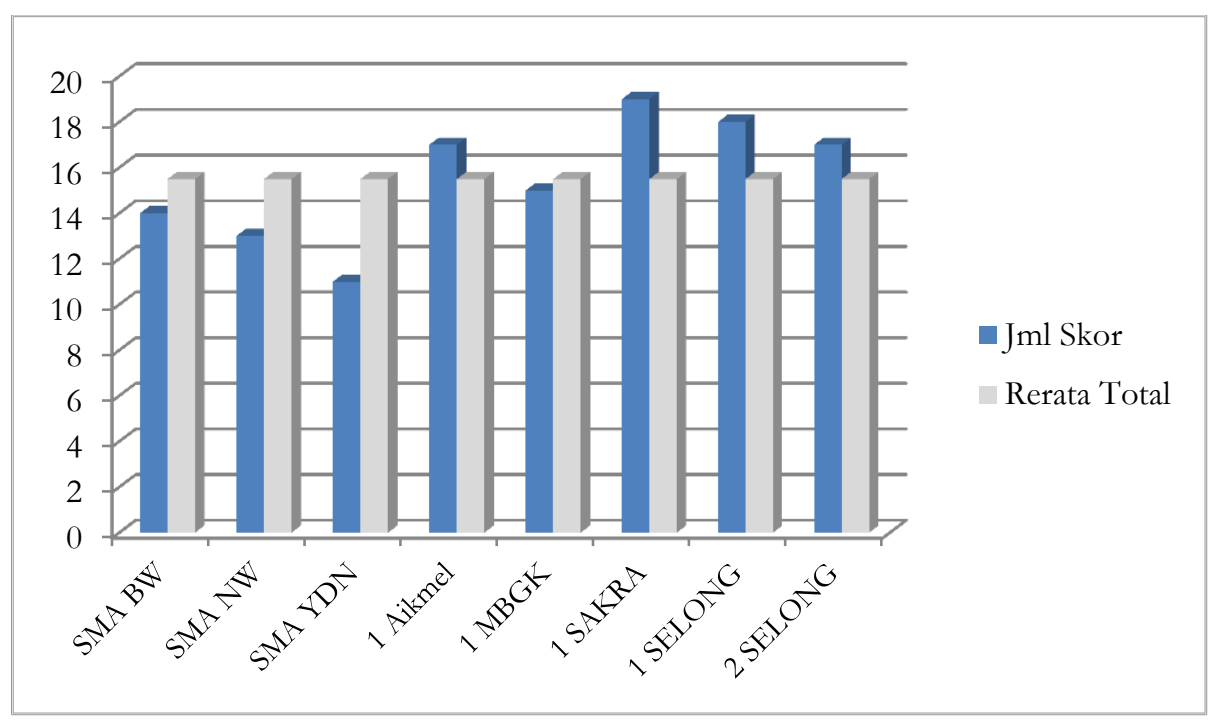

Gambar 2. Hasil Observasi Keseluruhan Kegiatan Pembelajaran di Kelas

Berbeda dengan hasil observasi, hasil pengolahan data instrumen angket menunjukkan bahwa pelaksanaan pembelajaran Seni Budaya SMA di Kabupaten Lombok Timur berada pada kategori kurang baik. Secara rinci, dapat dilihat dalam tabel berikut.

Tabel 7. Pencapaian Skor Angket

\begin{tabular}{ccc}
\hline Komponen & Pencapaian & Kategori \\
\hline $\begin{array}{c}\text { Persyaratan } \\
\text { pelaksanaan }\end{array}$ & \multirow{2}{*}{10,30} & $\begin{array}{c}\text { Kurang } \\
\text { baik }\end{array}$ \\
pembelajaran & & Kurang \\
Pelaksanaan & 33,70 & baik \\
pembelajaran & & \\
\hline
\end{tabular}

Tabel tersebut menunjukkan capaian rerata total jawaban 240 siswa di 8 (delapan) sekolah berdasarkan angket pelaksanaan pembelajaran untuk tiap komponen. Pencapaian rerata total jawaban siswa pada komponen persyaratan pelaksanaan pembelajaran sebesar 10,30 berada pada rentang 8,75 - 11,25 dengan kategori kurang baik. Apabila dikonversi menjadi persentase capaian skor, maka skor tersebut menunjukkan pencapaian sebesar $63,3 \%$.

Selanjutnya, pada komponen pelaksanaan pembelajaran, pencapaian rerata total jawaban siswa pada angket sebesar 33,70, berada pada rentang 28 - 36 dengan kategori kurang baik. Apabila dikonversi menjadi persentase capaian skor, maka skor tersebut menunjukkan pencapaian sebesar $67,4 \%$.

Hasil observasi dan hasil angket memang menunjukkan hasil yang berbeda. Hasil observasi menunjukkan pelaksanaan pembelajaran sesuai kriteria rerata ideal berada pada kategori baik. Akan tetapi, secara proporsi, terlihat pada Gambar 2 bahwa ada $50 \%$ sekolah yang capaian skornya berada di bawah rerata ideal. Sekolah dengan capaian skor rerata di bawah rerata total keseluruh. Sekolah dimaksud adalah SMA Birul Walidain Rensing, SMA NW Pancor, SMA Yadinu Masbagik, dan SMA N 1 Masbagik.

Pencapaian indikator yang masih rendah dalam pelaksanaan pembelajaran di sekolah-sekolah tersebut terkait belum maksimalnya guru dalam melaksanakan kegiatan inti pembelajaran. Kegiatan pembelajaran dimaksud terdiri dari kegiatan eksplorasi, elaborasi dan konfirmasi.

Pada kegiatan eksplorasi, beberapa kemampuan guru yang masih kurang yakni dalam menggunakan beragam pendekatan, media, dan sumber belajar; kurangnya kemampuan guru dalam memfasilitasi interaksi antarpeserta didik; tidak memfasilitasi peserta didik untuk praktek di studio atau sanggar; belum maksimal dalam melibatkan peserta didik secara aktif dalam kegiatan pembelajaran, termasuk dalam melibatkan peserta didik mencari informasi luas tentang materi atau topik yang diajarkan. 
Pada kegiatan elaborasi, guru Seni Budaya masih kurang dalam memberi kesempatan siswa untuk menganalisis masalah dalam pembelajaran; belum melaksanakan pembelajaran yang kooperatif; dan belum maksimal dalam memfasilitasi pajangan karya/presentasi peserta didik. Selain itu, pada kegiatan konfirmasi belum ada umpan balik dan penguatan yang diberikan kepada siswa serta belum maksimal dalam memfasilitasi refleksi materi peserta didik.

Hasil olahan data respon jawaban dari 240 responden siswa terhadap 21 butir angket juga menunjukkan bahwa guru Seni Budaya belum maksimal dalam melakukan kegiatan pembelajaran. Selain itu, hasil analisis terhadap 1 butir angket terkait kendala dan saran siswa terhadap pembelajaran Seni Budaya menunjukkan ada 3 hal yang menjadi kendala dalam pelaksanaan pembelajaran Seni Budaya, yakni kurangnya fasilitas, kurangnya keterampilan guru dalam mengajar, dan minat di bidang seni lainnya yang tidak dapat tersalurkan. Hal ini disebabkan sekolah hanya menyelenggarakan satu bidang seni.

Pembahasan hasil observasi dan hasil angket secara umum menunjukkan, belum maksimalnya guru dalam melaksanakan kegiatan pembelajaran dapat dikaitkan dengan kurangnya keterampilan mengajar yang dimiliki guru. Keterampilan mengajar dalam hal ini bisa jadi disebabkan karena latar be- lakang kualifikasi guru yang berasal dari disiplin ilmu nonseni, terutama guru Seni Budaya di sekolah swasta Islam yang merupakan lulusan Ma'had. Kualifikasi yang tidak sesuai dapat mempengaruhi pemahaman guru terhadap karakteristik pembelajaran Seni Budaya, sehingga kegiatan pembelajaran pun kurang maksimal. Berdasarkan uraian-uraian tersebut, dengan demikian dapat dikatakan bahwa pelaksanaan pembelajaran Seni Budaya SMA di kabupaten Lombok Timur masih kurang baik atau belum maksimal.

\section{Penilaian Pembelajaran}

Data penilaian pembelajaran Seni Budaya SMA di Kabupaten Lombok Timur diperoleh melalui penilaian dokumen atau perangkat penilaian pembelajaran Seni Budaya SMA yang dimiliki oleh guru, yang terdiri dari dokumen teknik penilaian pembelajaran, dokumen instrumen penilaian, dan dokumen analisis hasil pembelajaran. Penilaian dilakukan dengan cara mengecek ketersediaan dokumen-dokumen tersebut, dan diberi skor dengan rentang 1 s.d. 4.

Hasil pengolahan data menunjukkan, capaian rerata skor keseluruhan sebesar 7,88 berada pada kategori cukup baik dengan persentase pencapaian $80,8 \%$. Selanjutnya, perbandingan rerata skor total dengan rerata skor tiap sekolah dapat diamati pada gambar berikut.

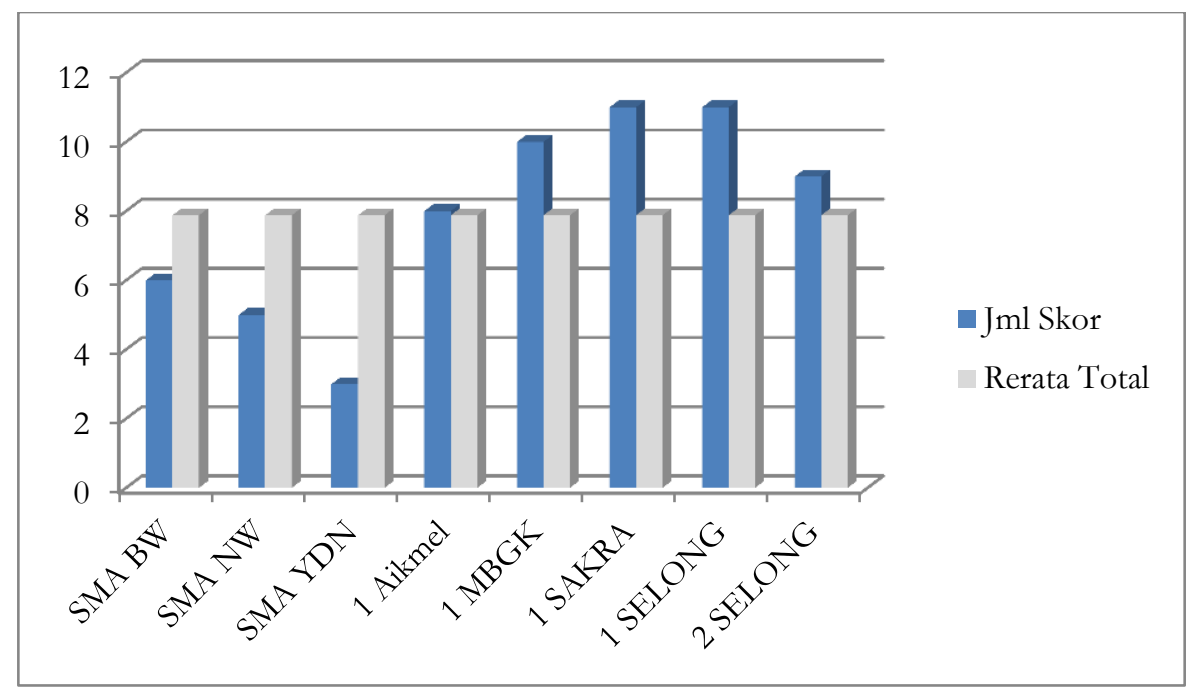

Gambar 3. Pencapaian Skor Penilaian Pembelajaran 
Diagram di atas menunjukkan bahwa ada perbedaan pencapaian skor penilaian pembelajaran di tiap sekolah dengan pencapaian rerata total semua sekolah. Diagram tersebut secara keseluruhan menunjukkan ada 3 (tiga) sekolah yang pencapaian skornya di bawah skor rerata total, yakni SMA Birul Walidain Rensing, SMA NW Pancor, dan SMA Yadinu Masbagik, sedangkan 5 (lima) sekolah lainnya memiliki capaian skor di atas rerata total. Pencapaian skor tertinggi dicapai SMA N 1 Sakra dan SMA N 1 Selong dengan skor total 11, dan capaian terendah dicapai SMA Yadinu Masbagik dengan rerata skor total 3 .

Perolehan skor di SMA Birul Walidain Rensing sebesar 6,00 berada di bawah rerata total keseluruhan sebesar 8,00. Pencapaian indikator yang masih rendah terlihat pada belum maksimalnya pelaksanaan tiap komponen penilaian pembelajaran. Hasil pengecekan dokumen menunjukkan bahwa guru Seni Budaya di sekolah ini, belum maksimal dalam memilih dan menggunakan teknik penilaian yang sesuai dengan karakteristik pembelajaran Seni Budaya. Hal ini terlihat dari kurang tersedianya dokumen penilaian yang dimiliki guru, dokumen yang dimiliki hanya dokumen penilaian tertulis dan penugasan. Selain itu, analisis hasil pembelajaran belum maksimal dilakukan. Hal ini Terbukti dari tidak ditemukannya dokumen-dokumen seperti analisis KKM dan analisis ulangan harian.

Demikian halnya dengan SMA NW Pancor dan SMA Yadinu Masbagik. Pencapaian skor di bawah rerata total keseluruhan dapat dilihat dari tidak tersedianya bukti fisik dokumen penilaian. Hasil pengecekan dokumen pada dua sekolah tersebut menunjukkan guru Seni Budaya belum maksimal dalam memilih dan menggunakan teknik penilaian. Teknik penilaian yang dilakukan masih belum menunjukkan perbedaan karakteristik antara mata pelajaran Seni Budaya dengan mata pelajaran lainnya. Hal ini dilihat dari dokumen yang tersedia yakni hanya dokumen tes tertulis dan penugasan. Selain itu, analisis hasil pembelajaran yang seharusnya dapat dimanfaatkan untuk per- baikan proses pembelajaran belum maksimal dilakukan.

Uraian hasil pengecekan dokumen penilaian pembelajaran pada ketiga sekolah di atas, secara garis besar menukik pada permasalahan terkait pemahaman guru terhadap karakteristik mata pelajaran Seni Budaya. Guru Seni Budaya SMA pada ketiga sekolah tersebut masih menganggap mata pelajaran Seni Budaya memiliki karakteristik yang sama dengan mata pelajaran lain. Hal ini terlihat dari teknik dan instrumen penilaian yang digunakan untuk menilai pembelajaran Seni Budaya yakni sebatas tes tertulis dan penugasan.

Permasalahan pemahaman guru pada ketiga sekolah tersebut terhadap karakteristik mata pelajaran Seni Budaya SMA apabila dikorelasikan dengan status sekolah swasta berlabel Islam, maka dapat dikatakan kurangnya pemahaman diakibatkan oleh kualifikasi guru yang berlatar belakang sarjana Pendidikan Agama Islam. Latar belakang nonseni tentunya akan menyulitkan guru dalam memahami karakteristik mata pelajaran Seni Budaya. Pemahaman mendalam terkait karakteristik tersebut dapat mengarahkan guru untuk memilih teknik dan instrumen penilaian yang tepat dan variatif untuk pembelajaran Seni Budaya.

Berbeda dengan ketiga sekolah tersebut, 5 (lima) sekolah lainnya yang dijadikan sampel tergolong cukup baik dalam melakukan penilaian pembelajaran Seni Budaya SMA di Kabupaten Lombok Timur. Dari kelima sekolah tersebut, dua diantaranya yakni guru SMA N 1 Sakra dan SMA N 1 Selong cukup baik dalam memilih dan menggunakan teknik serta instrumen penilaian. Dokumen penilaian yang dimiliki lengkap yakni terdiri dari dokumen observasi, penugasan, tes kinerja, dan tes tertulis. Oleh karena itu, berdasarkan uraian-uraian tersebut, secara keseluruhan penilaian proses pembelajaran Seni Budaya di Kabupaten Lombok Timur dapat dikatakan cukup baik.

Pengawasan Pembelajaran

Data pengawasan proses pembelajaran Seni Budaya SMA di Kabupaten Lom- 
bok Timur diperoleh melalui angket yang diberikan kepada responden yakni 8 orang kepala sekolah. Responden diberikan angket yang berisi 12 butir pertanyaan, terdiri 7 butir pertanyaan tertutup, dan 5 butir pertanyaan terbuka (3 butir isian, dan 2 butir tentang hambatan dan kemajuan pembelajaran Seni Budaya). Butir yang diberikan skor hanya 7 butir (pertanyaan tertutup) dengan rentang skor 1 s.d. 4.
Hasil pengolahan data diperoleh capaian skor rerata keseluruhan sebesar 16,00, sesuai rerata ideal berada pada kategori cukup baik dengan persentase pencapaian $70,3 \%$. Selanjutnya, perbandingan perolehan rerata skor keseluruhan dengan pencapaian rerata skor di tiap sekolah dapat diamati pada gambar berikut.

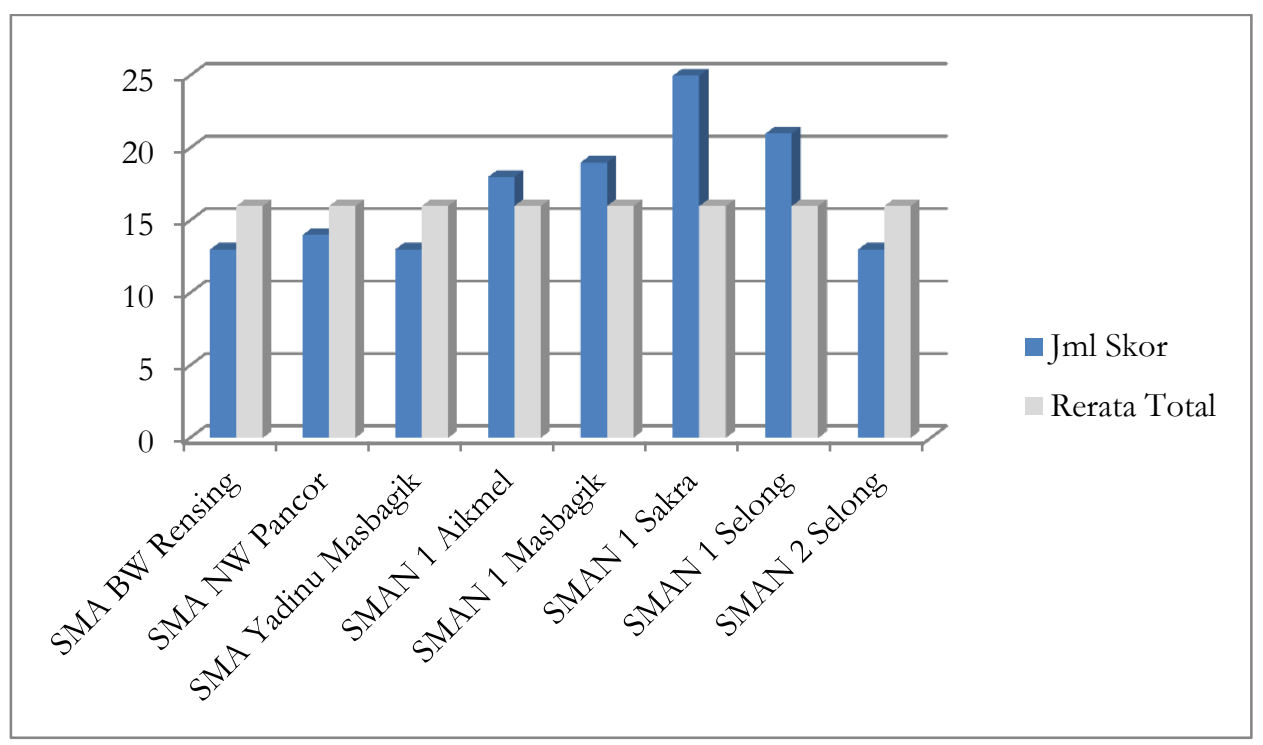

Gambar 4. Pencapaian Skor Pengawasan Pembelajaran

Diagram tersebut menunjukkan bahwa ada perbedaan pencapaian skor pengawasan pembelajaran di tiap sekolah dengan pencapaian rerata total semua sekolah, berdasarkan jawaban responden. Diagram tersebut secara keseluruhan menunjukkan ada 4 (empat) responden yang pencapaian skornya di bawah skor rerata total, yakni Kepala SMA Birul Walidain Rensing, Kepala SMA NW Pancor, Kepala SMA Yadinu Masbagik, dan kepala SMA N 2 Selong. Pencapaian skor tertinggi dicapai Kepala SMA N 1 Sakra dengan skor total 25, dan capaian terendah dicapai Kepala SMA Yadinu Masbagik, Kepala SMA Birul Walidain Rensing, dan Kepala SMA N 2 Selong.

Pencapaian skor pengawasan pembelajaran Seni Budaya di keempat sekolah tersebut disebabkan karena ada beberapa pencapaian indikator yang masih rendah. Pencapaian indikator yang masih kurang yakni dalam hal pemantauan yang dilakukan kepala sekolah dan pengawas Seni Budaya dari dinas setempat terhadap pelaksanaan pembelajaran Seni Budaya.

Pemantauan dilakukan kepala sekolah hanya 1 kali dalam satu semester. Pengawas Seni Budaya SMA di Kabupaten Lombok Timur pun tidak pernah melakukan pemantauan terhadap pelaksanaan pembelajaran Seni Budaya. Hal ini karena di Kabupaten Lombok Timur, pengawas Seni Budaya SMA di Kabupaten Lombok Timur tidak ada.

Selain itu, respon jawaban responden dalam pengawasan pembelajaran menunjukkan sekolah masih lemah dalam membuat dan mengembangkan silabus mata pelajaran Seni Budaya SMA. Pengembangan silabus dilakukan oleh guru sendiri, tanpa terlibat dalam KKG maupun MGMP Seni Budaya, dan dasar pengembangannya belum menye- 
luruh, masih mengacu pada satu komponen seperti Standar Isi.

Berdasarkan uraian-uraian tersebut, dapat dipahami bahwa pengawasan pembelajaran Seni Budaya SMA di Kabupaten Lombok Timur belum maksimal. Pengawasan pembelajaran yang belum maksimal dapat dilihat dari 50\% sekolah yang dijadikan sampel, pencapaian skornya masih berada di bawah rata-rata keseluruhan. Dengan demikian, berdasar hal tersebut secara keseluruhan pengawasan pembelajaran Seni Budaya SMA di Kabupaten Lombok Timur dapat dikatakan belum maksimal.

Relevansi Pelaksanaan Pembelajaran Seni Budaya di Kabupaten Lombok Timur dengan Standar Proses Permendiknas No. 41 Tahun 2007

Berdasarkan kajian dan uraian hasil penelitian serta pembahasan tiap komponen pelaksanaan pembelajaran yang terdiri dari perencanaan proses pembelajaran, pelaksanaan proses pembelajaran, penilaian proses pembelajaran, dan pengawasan proses pembelajaran, dapat dikatakan bahwa pelaksanaan pembelajaran Seni Budaya di Kabupaten Lombok Timur belum relevan dengan standar yang ditetapkan. Hal ini dapat dilihat dari temuan pada masing-masing variabel pelaksanaan pembelajaran.

Temuan pada variabel perencanaan proses pembelajaran menunjukkan, sebanyak $50 \%$ sekolah belum maksimal dalam pengembangan silabus dan belum maksimal dalam penyusunan RPP, terutama dalam penentuan media, alat, dan pendekatan pembelajaran serta pengorganisasian siswa. Temuan pada variabel pelaksanaan proses pembelajaran, komponen persyaratan pembelajaran hanya terlaksana $63,3 \%$, dan komponen pelaksanaan kegiatan pembelajaran terlaksana $67,4 \%$. Hasil observasi menunjukkan 50\% sekolah belum maksimal dalam melakukan kegiatan pembelajaran terutama dalam kegiatan eksplorasi, elaborasi, dan konfirmasi, yang disebabkan oleh kurangnya pemahaman dan keterampilan guru dalam mengajar Seni Budaya.
Selanjutnya, temuan pada variabel penilaian proses pembelajaran menunjukkan, sekolah masih belum maksimal dalam pemilihan dan penggunaan teknik serta instrumen penilaian sesuai karakteristik mata pelajaran Seni Budaya, dan temuan pada variabel pengawasan proses pembelajaran menunjukkan, sebanyak 50\% kepala sekolah belum maksimal dalam pengawasan kegiatan pembelajaran, dan belum ada pengawas khusus Seni Budaya dari dinas setempat. Dengan demikian, berdasarkan temuan-temuan tersebut maka dapat dikatakan pelaksanaan pembelajaran Seni Budaya SMA di Kabupaten Lombok Timur belum relevan dengan Standar Proses Permendiknas No. 41 Tahun 2007.

\section{Simpulan dan Saran}

Simpulan

Berdasarkan hasil penelitian dan pembahasan, maka kesimpulan penelitian ini sebagai berikut.

Perencanaan proses pembelajaran Seni Budaya SMA di Kabupaten Lombok Timur kurang baik, capaian rerata skor 50\% sekolah berada di bawah rerata ideal. Perencanaan pembelajaran yang belum maksimal terkait belum maksimalnya guru dalam penyusunan RPP, terutama dalam hal menentukan media, metode, pendekatan, dan alat pembelajaran; menentukan rancangan kegiatan pembelajaran; menentukan pengorganisasian siswa; dan menentukan teknik serta instrumen penilaian yang digunakan.

Pelaksanaan proses pembelajaran Seni Budaya SMA di Kabupaten Lombok Timur kurang baik. Secara keseluruhan, capaian rerata skor $50 \%$ sekolah dalam melaksanakan proses pembelajaran berada di bawah rerata ideal. Pada komponen persyaratan pelaksanaan pembelajaran hanya terlaksana $63,3 \%$ dan pelaksanaan kegiatan pembelajaran hanya terlaksana 67,4\%. Pencapaian indikator yang rendah terkait kurangnya kemampuan guru dalam mengelola pembelajaran, seperti dalam memfasilitasi kegiatan eksplorasi, elaborasi, dan konfirmasi proses pembelajaran peserta didik. 
Penilaian proses pembelajaran Seni Budaya SMA di Kabupaten Lombok cukup baik, akan tetapi masih ada 37,5\% sekolah yang belum maksimal dalam menentukan teknik dan instrumen penilaian yang digunakan untuk menilai pembelajaran Seni Budaya.

Pengawasan proses pembelajaran Seni Budaya di SMA Kabupaten Lombok Timur kurang baik, pencapaian rerata skor $50 \%$ sekolah berada di bawah rerata ideal. Pencapaian indikator yang masih rendah terkait kurangnya frekuensi pemantauan yang dilakukan oleh kepala sekolah. Selain itu, Kabupaten Lombok Timur tidak memiliki pengawas Seni Budaya SMA, akibatnya tidak pernah ada pengawasan dari dinas pendidikan setempat terhadap pelaksanaan pembelajaran Seni Budaya.

Secara umum, berdasarkan deskripsi hasil penelitian dan pembahasan menunjukkan ada kesenjangan antara pelaksanaan komponen perencanaan, pelaksanaan, penilaian, dan pengawasan pembelajaran dengan standar minimal pelaksanaan proses pembelajaran sebagaimana termuat dalam Permendiknas No. 41 Tahun 2007.

Saran

Berdasarkan kesimpulan hasil penelitian dan pembahasan pelaksanaan pembelajaran Seni Budaya SMA di Kabupaten Lombok Timur, maka dapat disarankan:

Kepada guru-guru Seni Budaya di SMA Kabupaten Lombok Timur untuk membuat kelompok musyawarah guru Seni Budaya. Kelompok musyawarah harus dilakukan guna memberikan wadah bagi guruguru dengan latar belakang nonseni, untuk dapat melakukan sharing dengan guru-guru berlatar belakang seni, walaupun jumlahnya tidak banyak.

Kepada para kepala sekolah untuk rutin melakukan pengawasan dan pemantauan terhadap kegiatan pembelajaran Seni Budaya. Hal ini agar kepala sekolah mengetahui keterbatasan guru maupun fasilitas yang dibutuhkan untuk menunjang kegiatan pembelajaran Seni Budaya.
Para guru Seni Budaya sebaiknya lebih memanfaatkan dan menambah referensi pengetahuan dan keterampilan di bidang teknologi dan informasi, agar dapat menunjang keterlaksanaan kegiatan pembelajaran.

\section{Rekomendasi}

Para guru Seni Budaya di SMA Kabupaten Lombok Timur yang belum maksimal dalam kegiatan pembelajaran dapat melengkapi diri dengan berbagai software pembelajaran, untuk menunjang keterlaksanaan kegiatan pembelajaran Seni Budaya. Adapun software yang dapat digunakan antara lain software Encore, Sibelius, Finale untuk pembelajaran Seni Musik, dan software Corel Draw untuk pembelajaran Seni Rupa.

Temuan sampingan pada penelitian ini menunjukkan, guru Seni Budaya di Sekolah swasta maupun sekolah negeri di Kabupaten Lombok Timur masih sangat kurang terutama di sekolah swasta. Seni Budaya di sekolah swasta diampu oleh guru lulusan Ma'had Islam yang memiliki kemampuan di bidang kaligrafi, dan masih banyak sekolah negeri yang pelajaran Seni Budayanya diampu oleh guru nonseni. Oleh karena itu, pemegang kebijakan di Kabupaten Lombok Timur harus segera mengatasi kekurangan guru Seni Budaya agar pembelajaran Seni Budaya dapat berlangsung dengan baik. Peneliti merekomendasikan agar Kabupaten Lombok Timur menjalin kerja sama dengan Universitas di luar NTB yang menyelenggarakan pendidikan seni seperti UNY, UPI, dan UNNES. Kerja sama dimaksud dalam bentuk memberikan beasiswa kepada putra dan putri daerah untuk melanjutkan studi di institusi-institusi tersebut, dengan syarat setelah menyelesaikan studi mereka kembali ke daerah asal untuk memnuhi kebutuhan guru Seni Budaya di SMA Kabupaten Lombok Timur.

Kepada pemegang kebijakan di Kabupaten Lombok Timur, mengamati latar belakang sekolah swasta di Lombok Timur yang kebanyakan berlatar belakang Islam, maka perlu ditinjau kembali kurikulum Seni Budaya yang digunakan, terutama bidang 
Seni Rupa. Bidang yang diajarkan di sekolah-sekolah tersebut adalah Seni Kaligrafi, semen-tara pada kurikulum tidak disebutkan ram-bu-rambu yang jelas untuk pelaksanaan pelajaran Seni Budaya bidang Seni Kaligrafi. Oleh karena itu, peneliti merekomendasikan agar dilakukan kerja sama dengan ahli Seni Rupa di luar daerah, untuk menyusun dan menyetarakan panduan khusus pelaksanaan pembelajaran Seni Budaya bidang Seni Kaligrafi, agar dapat digunakan pada sekolah swasta berlatar belakang sekolah Islam.

\section{Daftar Pustaka}

Azwar, Saifudin. 2012. Tes prestasi: fungsi dan pengembangan pengukuran prestasi belajar. Yogyakarta: Pustaka Pelajar.

Badan Pusat Statistik. (2011). Statistik kriminal 2011. Jakarta: BPS
Ghazali, Imam. 2010. Kompetensi guru seni budaya dalam pembelajaran seni musik di SMA Kota Pontianak Kalimantan Barat. Tesis. Bandung: Universitas Pendidikan Indonesia, diunduh 18 Juli 2012 pkl. 21.30 WIB melalui www.repository.upi.ac.id

KPP dan PA., Badan Pusat Statistik. (2011). Profil anak 2011. Jakarta: CV. Miftahur Rizky

Kementerian Pendidikan Nasional. (2006). Buku standar isi untuk satuan pendidikan dasar dan menengah. Jakarta: BSNP

Kementerian Pendidikan Nasional. (2007). Peraturan Menteri Pendidikan Nasional no. 41 tabun 2007 tentang Standar Proses untuk Satuan Pendidikan Dasar dan Menengah. Jakarta: BSNP. 